Journal of Applied Pharmaceutical Science Vol. 2 (10), pp. 081-085, October, 2012

Available online at http://www.japsonline.com

DOI: $10.7324 / J A P S .2012 .21016$

ISSN 2231-3354 (cc) BY-NC-SA

\title{
Phytomedicinal Studies of Kurram Agency in the Federally Administered Tribal Areas (FATA) of Pakistan
}

\author{
${ }^{1}$ Wahid Hussain, ${ }^{2}$ Javid Hussain, ${ }^{3}$ Roshan Ali, ${ }^{4}$ Sajid Hussain, ${ }^{5}$ Muhammad Ashfaq Khan, ${ }^{6}$ Ikhtiar Khan, ${ }^{7}$ Zabta khan \\ Shinwari, ${ }^{8}$ Wilson Araujo Lopes and ${ }^{2}$ Iracema Andrade Nascimento \\ ${ }^{1}$ Department of Plant Sciences, Kohat University of Science and Technology, Kohat, Pakistan \\ ${ }^{2}$ LABIOMAR, Institute of Biology, Campus Ondina, Federal University of Bahia, Brazil. \\ ${ }^{3}$ Institute of Basic Medical Science, Department of Biochemistry, Khyber Medical University, KPK, Pakistan. \\ ${ }^{4}$ Department of Pharmacy Havelian Campus Hazara Univerisity,Pakistan. \\ ${ }^{5}$ Department of Environmental Sciences COMSATS Institute Abbotabad, Pakistan. \\ ${ }^{6}$ Department of Plant Sciences,Quaid-i-Azem Univerity Islamabad,Pakistan. \\ ${ }^{7}$ Institute of Chemical Sciences University of Peshawar, Pakistan. \\ ${ }^{8}$ Institute of Chemistry, Campus Ondina, Federal University of Bahia, Brazil.
}

\section{ARTICLE INFO}

Article history:

Received on: 03/10/2012

Revised on: 16/10/2012

Accepted on: 22/10/2012

Available online: 29/10/2013

Key words:

Ethnomedicinal, Local recipe,

Chemical constituent,

Medicinal plants, Parachinar

Kurram Agency Pakistan.

\begin{abstract}
The present studies were aimed to identify medicinal plants, folk knowledge and to use local recipe for different diseases in the study area of kurram agency. The questionnaire method was adopted for documentation of folk indigenous knowledge. The Preliminary data were collected from the local community, experts, knowledgeable person, Herdsmen and main users of medicinal plants such as Hakims, old wise woman etc. The ethno medicinal data on 21 plants species belonging to 19 families were properly identified i.e. their vernacular names, chemical constituents, scientific names, families, part used, habitat conservative status and locality during the research work. The plants were collected, pressed dried, preserved, mounted and identified through the literature and were confirmed by the experts in plants sciences department, Kohat university of Science and Technology, Pakistan. The specimens were deposited in the herbarium at plant sciences department, Kohat University of Science and Technology, Pakistan.
\end{abstract}

\section{INTRODUCTION}

The study area is called Kurram agency Parachinar, Pakistan. Kurram agency, situated at the border of Afghanistan, is one of the seven tribal agencies in the Federally Administered Tribal Area (FATA). The major town of the agency, Parachinar, is close to the spot where 34th parallel of latitude crosses the 70th parallel (Stewart et al., 2003) and can be easily located on the map. The word "KURRAM" takes its name from river Kurram that passes through the length of the valley (Khan et al., 2005). The 12th century description of Kurram, as mentioned in the " Rig

* Corresponding Author

Javid Hussain, LABIOMAR, Institute of Biology,

Campus Ondina,Federal University of Bahia, Brazil.

Cell no: +557187003378 vide book" reveals that a Hindu spiritual leader named Karma hence the name Kurram River originated. After the Kurram River, the name of the area became "Kurram valley". The agency lays between 33.20 to 34.03 North latitudes and 69.50 to 70.45 East longitudes. Kurram Agency is bordered in the west and north by Afghan provinces of Paktia and Ningarhar respectively, in the East by Orakzai and Khyber Agencies, in the South East by Hangu District and in the South by North Waziristan (wikipedia.org/wiki/Kurram_Valley). The Agency is $115 \mathrm{Km}$ long with a total area of 3380 squares $\mathrm{Km}$. The administrative head quarter of the agency is Parachinar which is at a distance of $74 \mathrm{Km}$ from Thall on the main road. The research area in this work covers a total 87,742 hectares. It starts from Sultan in Southwest and end on Pewar Kotal (Durand line). 
The climate of Kurram varies at different altitudes and presents striking contrasts from sultry oppressive heat to bitter cold. Within a few hours journey, one can pass from a region where snow never falls to recesses where it never melts (Anonymous 2005). The climatic condition of Kurram is high land type. In January and February the climate is harsh from snow, rain and chill weather and sometimes fogy.

The lowest temperature at Kurram was recorded $-13.4^{\circ} \mathrm{C}$ on $29^{\text {th }}$ January 2005 and the highest temperature $39.9^{\circ} \mathrm{C}$ on $27^{\text {th }}$ June 2005 (Anonymous, 1999). The principal mountain range in the Agency is" KOH--E--SUFAID "or "SPINGHAR" with a peak of" SIKARAM SAR" which is 4,728 meters (15602 feet) high and forms a natural boundary and water shed with Afghanistan. It remains covered with snow throughout the year. The altitude of the town Parachinar is 5600 feet above sea level.

The Kurram River enters into the Agency in the West near Kharlachi from Afghanistan and runs in North West to the South East direction and leaves the Agency at Thall district. Several hill torrent and Nullahs join Kurram valley (Shinwari et at 2003). The research area i.e. Upper Kurram agency, starts from Sultan village and it ends on Teri mangle (Pewar Kotal). The people in the entire study area have reported "bombing" as a result of talibanizaion as a major cause of wild life disturbance. Forests depletion and absence of community capacity to manage and develop their natural resources were also causes of biodiversity depletion.

The use of plants in medicines is a very old and reliable practice. Medicinal plants remained the primary source of treatment throughout the world. Any plant or parts of plants like root, stem, leaf, bark, fruit, and seed which contain active chemical constituents in the tissue that produce a definite physiological response in the treatment of various diseases in human and in the animals are called medicinal plants (Bussmann et al., 2006). Plants produce complex organic molecules and therefore are considered rich sources of chemicals. These active chemicals extracted from plants and purified are used for medicinal purposes and are referred as herbal medicines [Khan et al., 2001].

Ethno botany is also the most important approach to study natural resource management of indigenous people. Ethno botany is the science of human interaction with plants and its ecosystem (Aburjai et al., 2006). By surveying the literature it has been concluded that only a single paper by Gilani et al., has been published on the ethno botany of five villagers of Upper Kurram (Zeran, Kirman, Shalozan, Pewar and Malana).

The people living in remote areas and in villages are using indigenous plants as medicines from long ago because this knowledge reaches to them through generation to generation (Mujtaba et al., 2006). They reported 21 medicinal plants belonging to 19 families.. Present studies covered the Medicinal plants' vernacular names, families name, scientific name, locality habitat, part used, chemical constituents and their status of the whole Uppe r Kurram agency medicinal plants.

\section{MATERIALS AND METHODS}

The field trips of 80 days duration to various parts of Kurram Agency were undertaken from February 2005 to April 2006 to collect various plants species of ethno medicinal importance present in the area in different seasons. All the relevant information and materials were collected and thoroughly studied before going into the field. The study trips mostly were scheduled according to the blooming seasons of different plant species. The trips for plant collection were made in spring seasons of 2005 and 2006. The main target sites in Parachinar kurram agency were Shalozan, Zeran,Kirman, Piwar, Krakhala and hill area of Malana \& Shalozan. The field work was also carried out in order to investigate the folk knowledge, vernacular names, scientific names, status of plants, family name and to determine the chemical constituents and other relevant information was noted in the field work. The collected material was pressed, dried using blotting papers for about two weeks at room temperature and identified though the available literature (Nasir et al., 2001) The field work plants were preserved, dried material was poisoned using mercuric chloride and absolute alcohol means 2 gram $\mathrm{HgCl} 2$ dissolved in $100 \mathrm{ml}$ ethyl alcohol. The plants were mounted on the standard size herbarium sheets. The local herds men, Hakim and local medicinal plants expert all were interviewed for ethnobotanical information of the area were collected.

\section{RESULTS AND DISCUSSION}

The energy stored in our food comes from sunlight. The solar energy is converted to usable energy by green plants. Photosynthesis by green plants is the main source of oxygen supply in the Earth's atmosphere. Plants provide us medicines, food, forage and fodder for our domestic animals, flowers, fuel wood, materials for making agricultural tools, timber and many more (Hussain et al., 1996).

The present study of medicinal plants provides information about therapeutic uses in different traditional recipes of 21 plants species belonging to 19 families. In this research we determined the botanical names, local names, common names, growth habits, parts used and their local recipes were documented [Table. 1]. Medicinal plants reported from this area have multiple uses e.g. Adiantum capillus locally used for skin allergy, Daphne mucronata good for skin allergy, Artimisia vulgars used for blood diseases (blood cancer), Artimisia absinthium is used for blood purification, and is antipyretic, Fumaria indica is a good drug for blood purification and antipyretic, Asparagus officinal is used for constipation, Bergenia ciliata is used for stomach problems, Mentha viridis is used in chest and stomach pain, Cannabis sativa is used as sedative and sexual stimulat, Datura stramonium is used for mental disorder, Equiestum arvense is useful in diarrhea, Plantago major is useful in diarrhea, Marrubium vulgare is used as antiseptic, Quercus ilex is used as anti-diabetes, Seriphidium kurramensis is a good anti-malarial drug, blood purifier and 
antipyretic, Viola canescens are used for cough, Cichorium intybus is used as antipyretic, Hypericum perforatum is used as carminative, and Papver somniferum capsule decoction are used as anti-cough. Market survey of the main city of Parachinar, Sadda, Village Bughday, Lalmay, Mulabagh, Shalozan, Pewar and Larzer was conducted. Based on the market survey it was identified that, there are no coordinated method in use for the collection and sale of medicinal plants, except Seriphdiumkurramensis, Artimisia absinthium, Teucrium stocksiannum, Tanacetium artemisioides and Morchella esculenta. The maximum produced medicinal plants are Seriphidium kurramensis, followed by Teucrium stocksianum and Artimisia absinthium because of their occurrence in the adjacent fields. Seriphidium kurramensis and Artimisia absinthium are traded from Lalmay, Bughday, Pewar and Larzer Shalozan. Both are anthelminthic in nature. Teucrium stocksianium was marketed from Pewar, Nastikot, Malikhial and Bughday and are used as insect repellent, antipyretic, blood purifier, antisugar and reduce obesity. In the study area, the above mentioned five species were available but Pewar, Shalozan and Lammay are famous for Seriphidium kurramensis and Artemisia absinthium whereas Bughday is famous for Teucrium stocksianum. There was one trader available at Kirman road, one in Shalozan and one in Pewar and Bughday road, who purchases plant material from local people, in dry form and finally carries it to Rawalpindi. That trader was belonging to Bajaur Agency. Based on discussion with local people it was concluded that season of Artemisia absinthium starts after Teucrium stocksianum (Gilani et al., 2003). Nowadays there is no trade except Artemisia absinthium and Morchella esculenta. In case of Morachella esculenta, children, men and women equally participate in the collection. The expensive more plant i.e. Morchellaesculenta is mainly collected by villagers living in the foothill of Koh-e-sufaid range (Pewar, Shalozan, Speenashga, Malana, Zeran, Mulabagh and Kirman).

There were five venders in Parachinar bazaar involved in the trade of Morchella esculenta, while three venders, one each on Shalozan Larzer road, Pewar Bughday and Kirman road dealing were trading in Artemisia absinthium and Teucrium stocksianum. From there it is carried to Lahore, Karachi and finally exported to France and Germany. There is no technical method used by the collector for the processing of medicinal plants. However they use local methods for drying, transportation and marketing the plants. Artemisia absinthium and Teucrium stocksianum are kept in a soft cloth for drying in the sunlight. In the past people used this practice for domestic uses of the plants and majority of the people were users of the plant material while contrary to this presently, awareness regarding the uses of medicinal plants has reduced and it has become limited to only commercial purposes. The reason given by the locals for decreasing trend of using folk knowledge of medicinal plants against the diseases is that more effective allopathic drugs have replaced that century's old traditional medicine. The people did not have problems in collecting those plants. Those living in the foothills of Kohe-sufaid (especially Saper Khel, Mullabagh, Arghanga kali, Landiwan, Mastayri Kali, Shalozan Thangia, Khaiwas, Nari Kali and Speenashga) had more approach to Morchellaesculenta because of its occurrence in those higher elevations. Other medicinal plants like Seriphidium kurramensis and Teucrium stocksianum were mostly in the use of lower parts of the Upper Kurram. Over grazing in research area is threatening the very existence of the medicinal plants. The conservation of the medicinal plants and their trade on sustainable basis must be ensured. The research area (Upper Kurram) is rich in term of biodiversity like flora, fauna and especially medicinal plants. The local community uses most of medicinal plants for their domestic purpose. Few local Hakims also make drugs for commercial purposes, which are sold in the market in two shops.

Kurram agency has a treasure of plant resources and diverse flora. However, sustainable use of these plants is necessary because ruthless use of these plants may cause the loss of valuable flora and fauna.

The primitive people had knowledge about medicinal plants that they had acquired on the trial and error basis. These plants are still used for the treatment of diseases in indigenous system of medicines, where the whole plant, plant part or its extracts is used. In Kurram agency the precious medicinal plants and tree is a need of further exploration of the area in this regard, the main aim of this traditional local used medicinal plants is to bring to the screen that what type of plants does the people of valley use medicinally. The conservation programme can protect the medicinal plants of kurram agency by participation of local community.

Table. 1: Medicinal plants using for local Recipes.

\begin{tabular}{|c|c|c|c|c|c|c|c|}
\hline S.No & Species & $\begin{array}{l}\text { Local Name } \\
\text { (Pashto) }\end{array}$ & $\begin{array}{l}\text { English } \\
\text { Name }\end{array}$ & Habitat & Constituents & Locality & Status \\
\hline \multirow[t]{2}{*}{1} & $\begin{array}{l}\text { Aconitum } \\
\text { heterophyllum Wall }\end{array}$ & Pishoser gull & $\begin{array}{l}\text { Pakistani } \\
\text { Atees }\end{array}$ & Herb & $\begin{array}{l}\text { Aconitic acid, heterophylline, aitisine, aconitine } \\
\text { andanthorine }\end{array}$ & $\begin{array}{l}\text { In hilly areas of upper } \\
\text { Kurram Agency }\end{array}$ & $\begin{array}{l}\text { Critical } \\
\text { Endangered }\end{array}$ \\
\hline & \multicolumn{7}{|c|}{ The rhizomes are first dried, crushed and a small amount is boiled in water to make the recipe. A cup is taken once or twice a day to improve the sexual desire } \\
\hline 2 & $\begin{array}{l}\text { Adiantum capillus } \\
\text { - veneris } \mathrm{L}\end{array}$ & Zulfi-e-laila & $\begin{array}{l}\text { Maidenhair } \\
\text { fern }\end{array}$ & Herb & $\begin{array}{l}\text { Tannine, heterosides of kaempferol, } \\
\text { hydroxyadiantone, quinic acid, flavonoid, } \\
\text { glucoside, luteolol and quercetol }\end{array}$ & Common in Kurram & Vulnerable \\
\hline & The whole plant is cr & shed and extrac & d; the juice is & plied on $\mathrm{i}$ & itants area of external body of humans, which give & f (Anti skin allergy). & \\
\hline \multirow[t]{2}{*}{3} & Allium sativum $\mathrm{L}$ & Wooga & Garlic & Herb & $\begin{array}{l}\text { Allicin, epinephrine, phyocidine, phytonides, } \\
\text { ascorbic acid and oxalic acid. }\end{array}$ & $\begin{array}{l}\text { Common cultivated in } \\
\text { Kurram agency. }\end{array}$ & Secured \\
\hline & $\begin{array}{l}\text { Bulb is used in high } \\
\text { also used as vegetabl }\end{array}$ & $\begin{array}{l}\text { ood pressure. T } \\
\text { for high blood }\end{array}$ & $\begin{array}{l}\text { e bulb is buri } \\
\text { essure. }\end{array}$ & in hot ashe & for twenty minutes and then eaten as such which is & effective for dry cough & \\
\hline 4 & $\begin{array}{l}\text { Artemisia vulgars } \\
\mathrm{L}\end{array}$ & Darlong & Warm seed & Herb & Scoparin, essential oil santonin and Succinic acid & Kurram Agency & Endangered \\
\hline
\end{tabular}




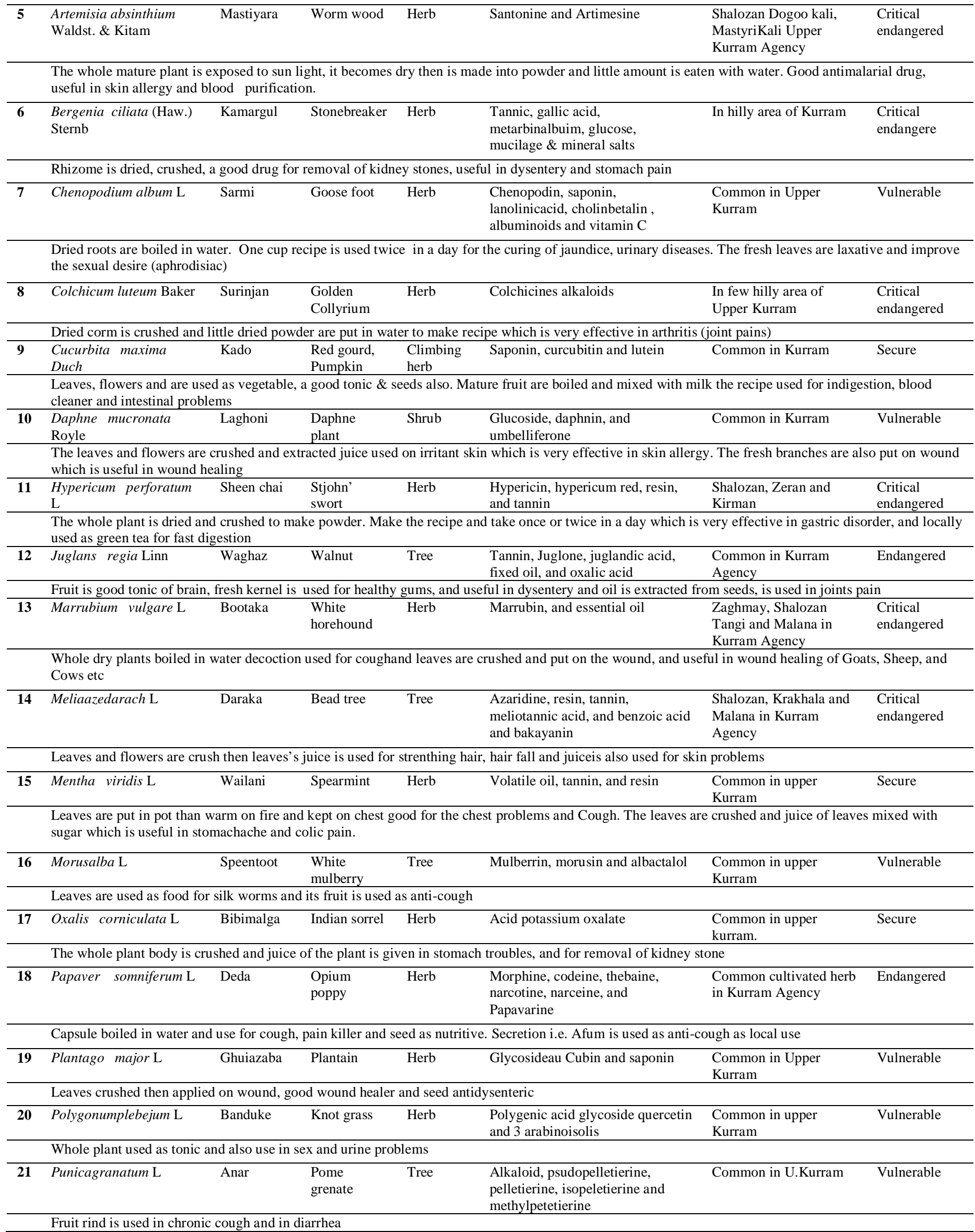




\section{CONCLUSION}

The present studies were aimed to identify medicinal plants, folk knowledge and to use local recipes for different diseases in the study area of kurram agency. The ethno medicinal data on 21 plants species belonging to 19 families were properly identified i.e. their vernacular names, chemical constituents, scientific names, families, part used, habitat conservative status and locality during the research work. The specimens were deposited in the herbarium at plant sciences department, Kohat University of Science and Technology, Pakistan to getting further information about them.

\section{REFERENCES}

Aburjai, T., Hudaib M.,Tavvem R.,Yousaf, M. and Qishawi, M. The study of Medicinal plants of Jordan, the Ailoun height region. Jordan. Journal Ethnobiol Ethno medicine 2006,47-52.

Anonymous, Metrological Pilot Balloon Observation Parachinar Kurram Agency, 2005.

Anonymous,District Census Report: Kurram Agency NWFP Statistical Division, Peshawar, Pakistan 1999.

Bussmann, $G$ and Sharon E. The traditional use of medicinal plants in Northern Peru, University of Hawaii, Lyon Arboretum, 3860 Manoa USA. Journal of Ethnobiology and medicine, 2006. 7: 2-47.

Gilani, S. S., Abbas S. Q., Shinwari Z. K., Hussain F. and Nargis K. 2003. Ehnobotanical study of Kurram Agency, Pakistan through Rural community participation, Pakistan.. Journal of Biological Sciences $2003,1368-1375$
Hussain, F., M., and Khaliq, A. Ethnobotanical studies on some plants of Dabargai Hills Swat. Proceeding of first training workshop on Ethnobotany and its application to conservation. NARC, Islamabad, 1996, 207-215.http://en.wikipedia.org/wiki/Kurram_Valley.

Khan, A. Ethnobotanical Potential, Phytosociology and Conservation Status of Mount Elum, Buner.Department of Bilogical Science Quaid-i-Azam University Islamabad. 2001, 19-25.

Khan, T. Gazetteer of Kurram Agency Parachinar. 2005, 43 47.

Mujtaba,G., Khan,M.,A., Common medicinal folk recipe of siran valley, Mansehra,Pakistan. Ethnobotanical leaflets. 2006;1: 49-62

Nasir,E.,and Ali,S.I., flora of Pakistan Fascicles,1971 -1999,1200.

225.

Nasir,E.,and Ali,S.I., flora of Pakistan Fascicles, 1971 -2001, 1-

Stewart, R. R., History and Exploration of plants in Pakistan and Adjoining areas, Flora of Pakistan, 2003.

Shinwari, Z. K., Gilani, S. S. and Mahboob-ur-Rehman. Medicinal and other useful Plants of district Swat, Pakistan.WWF Pakistan, 2003, 34-36.

\section{How to cite this article:}

Wahid Hussain, Javid Hussain, Roshan Ali, Sajid Hussain,Muhammad Ashfaq Khan,Ikhtiar Khan, Zabta khan Shinwari, Wilson Araujo Lopes and Iracema Andrade Nascimento. Phytomedicinal Studies of Kurram Agency in the Federally Administered Tribal Areas (FATA) of Pakistan. J App Pharm Sci. 2012; 2 (10): 081-085. 